\title{
Increasing Rice Production Eliminating the Vicious Chain of Food Gap: The Review of Long-Term Outlook of Rice Sector in Bangladesh
}

\author{
Md Shah Alamgir ${ }^{1 *}$, Mostafiz Rubaiya Binte ${ }^{2}$, Md Rashid Ahmed ${ }^{1}$, Md Monjurul Islam³ , Md Monirul Islam² and \\ Jasim Uddin Ahmed ${ }^{4}$
}

${ }^{1}$ Department of Agricultural Finance and Banking, Sylhet Agricultural University, Bangladesh

${ }^{2}$ Graduate School of Life and Environmental Sciences, University of Tsukuba, Japan

${ }^{3}$ Department of Rural Development, Bangabandhu Sheikh Mujibur Rahman Agricultural University, Bangladesh

${ }^{4}$ Department of Agricultural Economics and Policy, Sylhet Agricultural University, Bangladesh

Submission: May 21, 2019; Published: June 11, 2019

*Corresponding author: Md. Shah Alamgir, Department of Agricultural Finance and Banking, Sylhet Agricultural University, Sylhet, Bangladesh

Abstract

Rice is the main cash crop and staple food for people of Bangladesh. Per capita consumption of rice is about $170 \mathrm{~kg}$ per year. After independence, rice production gradually increases in Bangladesh, however due to population pressure; a sharp gap exists between production and consumption during the period of 1972 to 2008. Despite pressure from overpopulation, Bangladesh has reached self-sufficiency in rice production and secured fourth position among the highest rice producing countries in the world.

Keywords: Rice production; Food gap; Long-term outlook

\section{Introduction}

Bangladesh is an agriculture-based country in the world. Many cash crops are producing by the farmers of this country such as, rice, wheat, potato, jute etc. However, rice is the most important and number one crop according to production and staple food for people of Bangladesh. After liberation war in 1971, this country faced lots of crisis due to war that were infrastructural damage, food shortage, lack of resource person etc. This country overcome the great famine in 1974 due to shortage of food. However, after that period the country runback to food production and increased the rice production.

Rice grown throughout the country except some of hilly areas. Agro climatic condition of the country are suitable for growing different agricultural crops in year-round of this country. In Bangladesh, Agriculture contributes $15.35 \%$ of the gross domestic product (GDP); in addition, rice and other crops contributes $8.35 \%$ [1].

The population of Bangladesh increasing over the period, land and other natural resources facing the high pressure however, Bangladesh has made significant advancement in food production over the last three and a half decades [2].Rice is the main crop of Bangladesh and staple food, reflected in the high per capita rice consumption in this country. For getting the nutritional demand people of this country used rice. Due to cultivation techniques and cropping patterns rice production in Bangladesh has gradually changed in terms of yield potentials. Despite pressure from overpopulation, the country has reached self-sufficiency in rice production [3].

There has been quite improvement in terms of food grain availability over the years. In fact, per capita availability of rice has increased $137 \mathrm{~kg}$ in 1972 to $172 \mathrm{~kg}$ in 2013. Even though population has increased tremendously by this period implying an overall increase in food demand. Despite the significant increase in rice production Bangladesh is still one of the largest food grain importers in the world [4]. However, assessment of long-term rice supply scenario in Bangladesh could be of enormous use for the research managers, planners to take decision for the improvement of this sector.

\section{Methodology}

This study used secondary data for the analysis of rice scenario in Bangladesh. A time series data regarding area, production, yield etc. of rice from 1972 to 2013 (42 years) collected from International Rice Research Institute (IRRI), FAOSTAT, Bangladesh Bureau of Statistics (BBS), and other different published and unpublished reports of related studies. 
The present study employed in analyzing the data mainly for descriptive statistics. In descriptive analysis, to derive meaningful findings, the tabular technique and graphs used to classify the generated data [5].

\section{Results and Discussion}

\section{World rice production}

Rice is the most important foods in the world, and it contains many priceless health benefits. The production of rice has increased steadily over the decade. World's most consumed staple food is cultivated mainly in Asian countries. These countries produce rice to meet their own demand as well as export to other countries.

According to the statistics of world rice production in 2016, China is highest rice producing country in the world. According to the USDA estimates in 2016, the world rice production is 480.02 million metric ton where Bangladesh achieved the fourth position shows red colored in Figure 1.

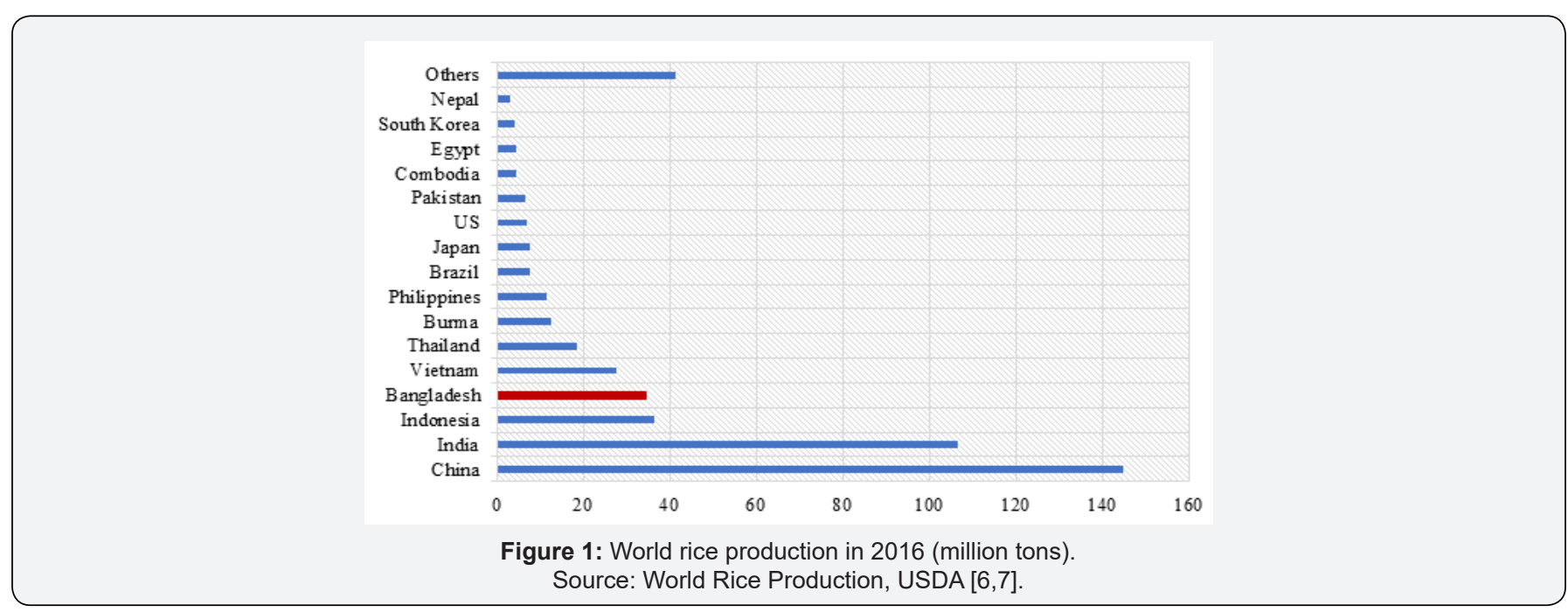

\section{Rice production in different season}

In Bangladesh, three kinds of rice are producing by farmers', which are aus, aman, and boro (Table 1). Aman area covered most of the Bangladesh, but the yield rate is lower than the boro production. The boro production increases over the periods due to the increasing rate of yield. Moreover, farmers are using modern variety for all kinds of rice production. However, area of aus production increases but not the significant increases of yield. It appears that during the last two decades the boro crop has had a higher share in total production than the aman rice, which was the major rice crop in Bangladesh. High yielding Table 1: Area, production, and yield rate of rice in Bangladesh. seeds and irrigation helped Bangladesh attain faster growth in expansion of cultivation of boro rice.

Due to the population pressure, Bangladesh faced the food insecurity on the beginning years of independence and high yielding variety of boro rice production meet up the demand of food in Bangladesh. Now a day's boro is main rice, which are cultivated by farmers in Bangladesh. Table 1 shows the yield of boro rice production for the last eras and in 2014-15 season it reached nearly 4.00 ton per hectare while aman 2.38 , and aus 2.24 respectively. Although this yield rate is lower, compare to other rice producing countries in world.

\begin{tabular}{|c|c|c|c|c|c|c|c|c|c|}
\hline \multirow{3}{*}{ Year } & \multicolumn{9}{|c|}{ (Area in Million Hectares and Production in Million Metric Tons, and Yield in t/ha) } \\
\hline & \multicolumn{3}{|c|}{ Aus } & \multicolumn{3}{|c|}{ Aman } & \multicolumn{3}{|c|}{ Boro } \\
\hline & Area & Production & Yield & Area & Production & Yield & Area & Production & Yield \\
\hline 2007-08 & 0.91 & 1.5 & 1.64 & 5.05 & 9.66 & 1.91 & 4.6 & 17.76 & 3.86 \\
\hline 2008-09 & 1.07 & 1.9 & 1.76 & 5.5 & 11.61 & 2.11 & 4.71 & 17.8 & 3.78 \\
\hline 2009-10 & 0.98 & 1.71 & 1.74 & 5.67 & 12.2 & 2.15 & 4.7 & 18.05 & 3.84 \\
\hline $2010-11$ & 1.11 & 2.13 & 1.91 & 5.64 & 12.8 & 2.26 & 4.77 & 18.61 & 3.9 \\
\hline 2011-12 & 1.14 & 2.33 & 2.04 & 5.58 & 12.79 & 2.29 & 4.81 & 18.75 & 3.89 \\
\hline 2012-13 & 1.05 & 2.15 & 2.05 & 5.61 & 12.89 & 2.29 & 4.77 & 18.77 & 3.93 \\
\hline 2013-14 & 1.05 & 2.32 & 2.2 & 5.54 & 13.02 & 2.35 & 4.8 & 19 & 3.95 \\
\hline 2014-15 & 1.04 & 2.33 & 2.24 & 5.53 & 13.19 & 2.38 & 4.84 & 19.19 & 3.96 \\
\hline
\end{tabular}

Source: Bangladesh Bureau of Statistics [8]. 
Rice production trend in Bangladesh from 1972 to 2013

Food security means rice security in Bangladesh. It provides income, employment, and food directly or indirectly for more than $70 \%$ of the peoples. From rice deficit to almost self-sufficient for some of the years in last decade. The Figure 2 indicates that total rice production area in Bangladesh not increasing over the period and it is about 10 million ha. However, the total production increases during the period and great change of rice production in after the year 2000. Moreover, average yield rate of rice is about 4 tons per hectare.

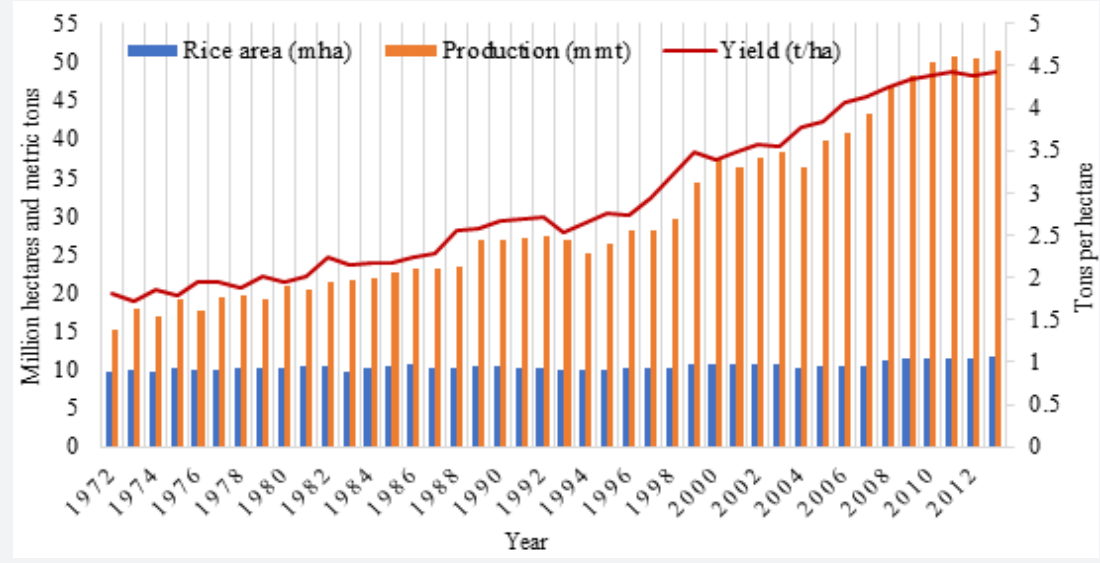

Figure 2: Trend of area, production and yield of rice in Bangladesh. Source: IRRI [7].

Bangladesh is the leading country to produce rice all over world. The trend of paddy (with husk rice) production tremendously increasing after 1995. The dramatic increase of paddy production in last decade and reached more than 50 million metric tons, which followed for milled rice production. There is a certain gap between production and consumption of milled rice in Bangladesh (Figure 3). This situation influences to import milled rice or other food grain from different countries. In the very beginning of Bangladesh, there is no big gap; however, after 1985 to 2000, there was a big gap in total production and consumption. However, in the year of 2000 the production and consumption made a balance between consumption and production. Furthermore, from 2001 to 2007 shows the national gap between the production and consumption of milled rice.

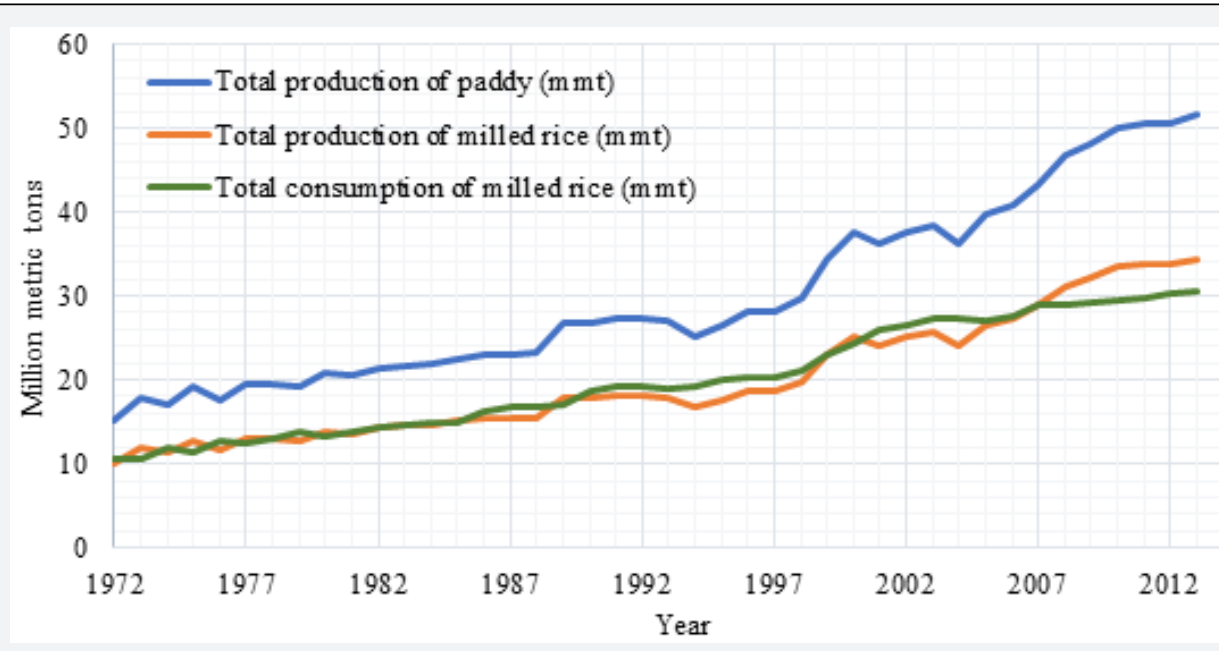

Figure 3: Production and consumption of rice over the years. Source: IRRI [7].

Remarkably, after 2007 the country overcome the negative situation and change to surplus situation of rice production. Now Bangladesh enjoy the surplus rice production and fully rice secured country. This result indicates the self-sufficiency of rice production in Bangladesh.

\section{Per capita consumption of rice}

Population is a key factor in rice consumption. Generally, the people of Bangladesh consume different kinds of food items however, rice is the staple dietary item, and per capita consumption of rice is about $171 \mathrm{~kg} /$ year [8]. The Figure 4 
shows the increasing trend of per capita consumption of rice in Bangladesh. Although in the year of 1997 is slight decrease however after that period again increase and reached to $170 \mathrm{~kg} /$ year.

The Figure 4 shows the increasing trend of per capita of rice consumption in Bangladesh during the period of 1972-2013. In addition, after the year 2000, it was dramatically increased and reached more than $170 \mathrm{~kg} /$ year. The accomplishment of the
Green Revolution in the early 1960s witnessed a steady rise in Asia's per capita rice consumption from 85 kilograms per year in the early '60s to nearly 103 kilograms in the early' 90 s. On the other hand, global per capita consumption rose from 50 to 65 kilograms per annum during the same period. The rising per capita consumption plus the growing population more than doubled global rice consumption during this period from 150 to 350 million tons [9].

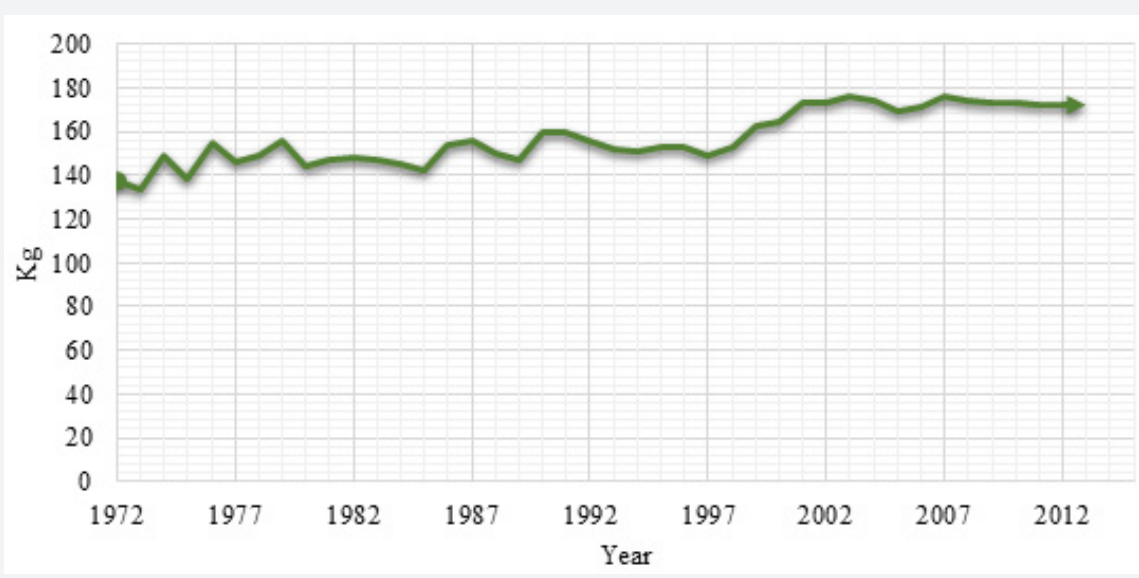

Figure 4: Per capita consumption of rice (kg/yr). Source: IRRI [7].

\section{Import and export of rice in Bangladesh}

Many studies indicate that Bangladesh achieving near selfsufficiency in food grain production; however, this country is still one of the largest food grain importers in the world (Figure 5). To keep dive with the increasing demand emanating from population growth, government kept on continuing the import of food grains. From the figure, after liberation war of Bangladesh in 1971 started to import rice and continue to till date. The trend of rice import fluctuating over the years and highest import was in the year of 1999 and it was more than 2 million metric tons, which followed to the rest of the years. It is worth mentioning that the volume of food grain import was more than doubled compare to the amount of 1992 with the amount imported in 1999, which followed rest of the years. Rice production fully damaged due to long-term flood in 1998 and influenced the import of rice in 1999. Private imports (Imports from India) contributed a lot in 1998 and 2002 when there were production shocks but during the price, hikes in 2007-08 it did not work because of the export restrictions of India.

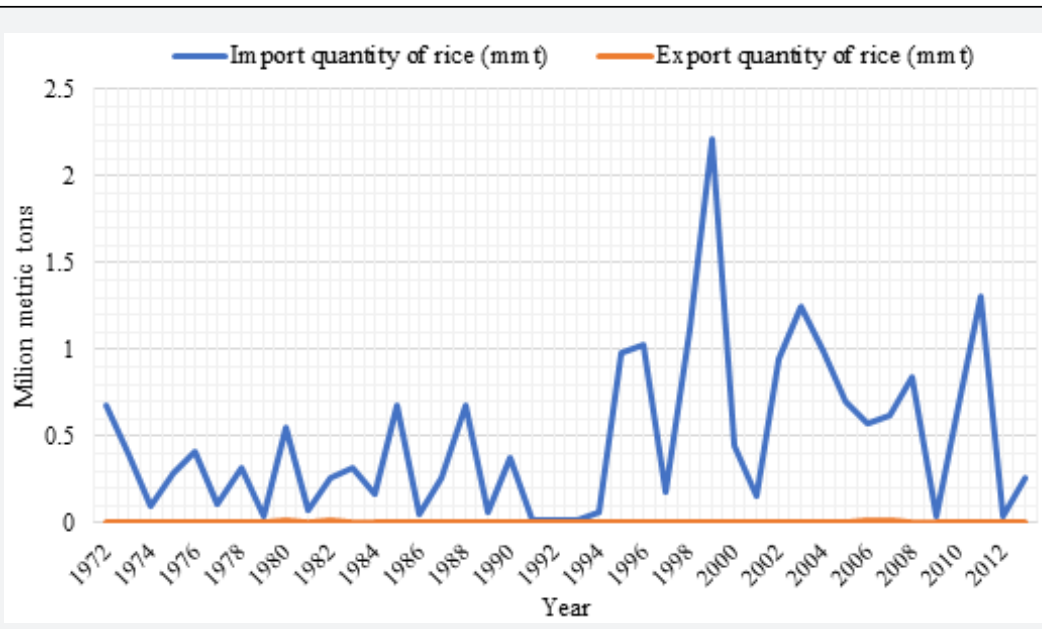

Figure 5: Import and export of rice over the years. Source: IRRI [7]. 


\section{Food grain production in Bangladesh}

After independence to till now during the last three decades Bangladesh, achieved a tremendous progress in agriculture [10]. Modern technology has made a remarkable impact on output growth. The rapid growth of modern inputs has had a positive impact on food-grain production.

Bangladesh has achieved significant improvement in food production particularly in rice production since the independence of Bangladesh. Since independence rice, production has increased from 11 million metric tons to 34 million metric tons [1]. This significant improvement in agriculture can largely be attributed

Table 2: Food grains production in Bangladesh.

\begin{tabular}{|c|c|c|c|c|c|c|c|c|c|c|c|}
\hline Food Grains & $\mathbf{2 0 0 0 - 0 1}$ & $\mathbf{2 0 0 2 - 0 3}$ & $\mathbf{2 0 0 7 - 0 8}$ & $\mathbf{2 0 0 8 - 0 9}$ & $\mathbf{2 0 0 9 - 1 0}$ & $\mathbf{2 0 1 0 - 1 1}$ & $\mathbf{2 0 1 1 - 1 2}$ & $\mathbf{2 0 1 2 - 1 3}$ & $\mathbf{2 0 1 3 - 1 4}$ & $\mathbf{2 0 1 4 - 1 5}$ & $\mathbf{2 0 1 5 - 1 6}$ \\
\hline Aus & 1.91 & 1.85 & 2.29 & 2.1 & 2.22 & 2.13 & 2.33 & 2.16 & 2.33 & 2.33 & 2.29 \\
\hline Aman & 11.25 & 11.11 & 11.01 & 12.23 & 12.66 & 12.79 & 12.8 & 12.9 & 13.02 & 13.19 & 13.48 \\
\hline Boro & 11.92 & 12.22 & 18.68 & 18.29 & 18.53 & 18.62 & 18.76 & 18.78 & 19.01 & 19.19 & 18.94 \\
\hline Total Rice & 25.08 & 25.18 & 31.98 & 32.61 & 33.4 & 33.54 & 33.89 & 33.83 & 34.36 & 34.71 & 34.71 \\
\hline Wheat & 1.67 & 1.5 & 0.96 & 0.96 & 1.04 & 0.97 & 1 & 1.26 & 1.3 & 1.35 & 1.35 \\
\hline Maize & 0.149 & 0.175 & 2.36 & 1.14 & 1.37 & 1.55 & 1.95 & 2.18 & 2.52 & 2.36 & 2.64 \\
\hline Total & 26.9 & 26.87 & 35.29 & 34.71 & 35.81 & 36.07 & 36.84 & 37.27 & 38.17 & 38.42 & 38.69 \\
\hline
\end{tabular}

Source: BER [1].

\section{Nutritional status from rice over the period}

Most of the developing countries like Bangladesh; rice is the primary source of nutrition. Rice has generally been considered as the main food to improve the food insecurity. It is currently food grain production has more than doubled since independence in 1971. However, until now food insecurity is a big issue in Bangladesh. Table 3 shows that, percentage of total Table 3: Calorie intake from rice in Bangladesh.

\begin{tabular}{|c|c|c|c|c|c|}
\hline Year & $\begin{array}{l}\text { Consumption per } \\
\text { Capita }(\mathrm{kg} / \mathrm{yr})\end{array}$ & $\begin{array}{c}\text { Calorie Intake } \\
\text { (\%total/day) }\end{array}$ & $\begin{array}{l}\text { Calorie Intake per } \\
\text { Capita (kcal/day) }\end{array}$ & $\begin{array}{c}\text { Fat Intake (\%total/ } \\
\text { day) }\end{array}$ & $\begin{array}{c}\text { Protein Intake } \\
\text { (\%total/day) }\end{array}$ \\
\hline 1972 & 137.65 & 73.04 & 1371 & 20.84 & 61.36 \\
\hline 1981 & 147.38 & 73.47 & 1468 & 21.47 & 63.48 \\
\hline 1991 & 159.94 & 75.28 & 1593 & 18.39 & 66.09 \\
\hline 1992 & 156.09 & 73.66 & 1555 & 15.77 & 65.13 \\
\hline 1993 & 151.41 & 75.02 & 1508 & 16.8 & 66.01 \\
\hline 1994 & 151.05 & 75.14 & 1505 & 17.55 & 65.05 \\
\hline 1995 & 153.22 & 74.79 & 1528 & 16.51 & 65.33 \\
\hline 1996 & 152.85 & 74.41 & 1524 & 16.08 & 64.8 \\
\hline 1997 & 148.56 & 70.61 & 1480 & 12.7 & 62.03 \\
\hline 1998 & 153 & 70.57 & 1525 & 10.89 & 63.25 \\
\hline 1999 & 162.73 & 71.54 & 1621 & 14.94 & 61.23 \\
\hline 2000 & 163.94 & 72.32 & 1633 & 13.18 & 63.31 \\
\hline 2001 & 172.9 & 73.92 & 1723 & 13.97 & 65.03 \\
\hline 2002 & 172.94 & 74.49 & 1723 & 16.06 & 63.58 \\
\hline 2003 & 175.95 & 74.6 & 1753 & 14.99 & 64.3 \\
\hline 2004 & 174.21 & 72.88 & 1736 & 14.26 & 62.19 \\
\hline
\end{tabular}




\section{International Journal of Environmental Sciences \& Natural Resources}

\begin{tabular}{|l|l|l|l|l|l|}
\hline 2005 & 169.41 & 71.16 & 1688 & 13.61 & 12.93 \\
\hline 2006 & 171.11 & 71.88 & 1705 & 13.56 & 61.74 \\
\hline 2007 & 176.07 & 72.57 & 1754 & 13.89 & 61.28 \\
\hline 2008 & 174.27 & 72.76 & 1736 & 12.95 & 52.52 \\
\hline 2009 & 173.13 & 71.13 & 1725 & 13.22 & 58.66 \\
\hline 2010 & 172.79 & 70.56 & 1721 & 12.83 & 59.9 \\
\hline 2011 & 172.62 & 70.81 & 1720 & 12.56 & 59.08 \\
\hline 2012 & 172.47 & 70.55 & 1718 & 12.63 & 57.56 \\
\hline
\end{tabular}

Source: International Rice Research Institute (IRRI), 2017.

\section{Conclusion}

This study has presented detailed of the rice production, consumption, and import-export scenarios of Bangladesh. In this paper, our main effort was to find out the yield of production, and consumption trend of rice in Bangladesh. We compared the world rice production among the rice producing countries including Bangladesh as well as the area, yield, and total production of Bangladesh over the last 42 years. About $80 \%$ of people in Bangladesh depend directly on agriculture for their food and livelihood, and rice being the first most vital crop. Natural calamity and climate change influenced strongly on rice production. However, our study found that, the rice production gradually increased after independence of Bangladesh and now a days Bangladesh become the leading position of rice growing countries in the world. This increasing trend of rice production have direct implications for food security in Bangladesh as well as South Asia.

\section{References}

1. Bangladesh Economic Review (2016) Finance Division, Ministry of Finance, Government of the People's Republic of Bangladesh, November 2016.

2. Alam SM, Islam MA (2013) Long-Term Assessment of Rice Production Scenario in Bangladesh: A Macro Dynamics. Bangladesh J Agril Res 38(2): 257-269.
3. Israt JS, Misuzu TN, Mana KN, Mohammad SH, Yoshiaki I (2016) Rice Cultivation in Bangladesh: Present Scenario, Problems, and Prospects. J Intl Cooper Agric Dev 14: 20-29.

4. Akhter S, Sarker JR, Das KR (2016) Growth and Trend in Area, Production and Yield of Major Crops of Bangladesh. International Journal of Economics, Finance and Management Sciences 4(1): 20-25.

5. Food and Agriculture Organization FAO-STAT (2012) Food and Agriculture Organization (FAO), Statistical database.

6. United States Department of Agriculture (USDA) (2017) World Rice Production, Economic Research Service, USDA, WDC, USA.

7. World Rice Statistics WRS (2017) International Rice Research Institute, (IRRI)

8. Bureau of Statistics (2015) Yearbook of Agricultural Statistics, Government of the People's Republic of Bangladesh, July 2016.

9. Mohanty S (2013) Rice Facts, Trends in Global Rice Consumption, Rice Today, January-March 2013, pp. 44-45.

10. Islam N (2012) Impact of Modern Technology on Food Grain, 18th Biennial Conference 2012, Bangladesh Economic Association, Dhaka.

11. Bhuiyan NI, Paul DNR, Jabber MA (2002) Feeding the Extra Millions. In: Proceedings of the BRRI-DAE Workshop on Experiences of HYV Rice Production in Bangladesh, Bangladesh Rice Research Institute, Gazipur-1701.
Your next submission with Juniper Publishers will reach you the below assets

- Quality Editorial service

- Swift Peer Review

- Reprints availability

- E-prints Service

- Manuscript Podcast for convenient understanding

- Global attainment for your research

- Manuscript accessibility in different formats

( Pdf, E-pub, Full Text, Audio)

- Unceasing customer service

Track the below URL for one-step submission https://juniperpublishers.com/online-submission.php 